\title{
WILD \\ PLANTS IN TRADE
}

Martin Jenkins \& Sara Oldfield

A TRAFFIC NETWORK REPORT

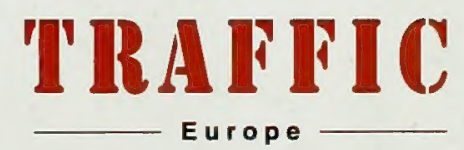

This report was published with the kind support of

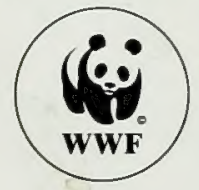


Published by TRAFFIC International,

Cambridge, United Kingdom.

With financial support from

WWF UK (World Wide Fund For Nature).

(C) 1992 TRAFFIC International.

All rights reserved.

All material appearing in this publication is copyrighted and may be reproduced with permission. Please credit: TRAFFIC International - Headquarters of the TRAFFIC Network, the wildlife trade monitoring programme of WWF and IUCN.

The views of the author expressed in this publication do not necessarily reflect those of the TRAFFIC Network, WWF or IUCN.

The designations of geographical entities in this publication, and the presentation of the material, do not imply the expression of any opinion whatsoever on the part of TRAFFIC or its supporting organizations concerning the legal status of any country, territory, or area, or of its authorities, or concerning the delimitation of its frontiers or boundaries.

ISBN 0947613897 
WILD PLANTS IN TRADE

Martin Jenkins and Sara Oldfield 


\section{SOURCES OF INFORMATION}

Preface 1

Introduction $\quad 3$

Species reviews 11

Orchids 11

$\begin{array}{ll}\text { Bulbs } & 18\end{array}$

$\begin{array}{ll}\text { Cycads, palms and tree ferns } & 21\end{array}$

$\begin{array}{ll}\text { Cacti and succulent plants } & 24\end{array}$

$\begin{array}{ll}\text { Carnivorous plants } & 27\end{array}$

Air plants $\quad 29$

Sources of information $\quad 31$

Useful addresses $\quad 32$

$\begin{array}{ll}\text { Annex I } & 33\end{array}$

$\begin{array}{ll}\text { Notes } & 36\end{array}$ 


\section{PREFACE}

\section{The European market for wild plants}

With a population of some 300 million and centuries of gardening tradition, Western Europe is undoubtedly the world's largest market for horticultural products. To a large extent the countries within Western Europe, and particularly those belonging to the EC, already act as a single market for horticultural plants, the main hub of the trade being the Netherlands. While there are innumerable outlets where common horticultural plants can be bought, the number of nurseries supplying a wide range of specialist plants to the dedicated collector in Europe is relatively small. Many of these have an international reputation and collectors travel across Europe to visit them, knowing where the rarities can be found.

Although the great majority of plants in trade, both in specialist nurseries and general horticultural outlets, are artificially propagated, it is known that a significant number of wildcollected plants still appear for sale. However the extent and importance of this trade has remained largely unknown.

\section{TRAFFIC's European nursery survey}

To try to determine the extent of trade in wild-collected plants in Europe, TRAFFIC Europe carried out a six-month investigation during 1991, funded by WWF and the United Kingdom Department of the Environment. Nursery surveys took place in eight countries (Belgium; France; Germany; Italy; the Netherlands; Spain (Canary Islands); Switzerland and the United Kingdom) and information was gathered by other means from other EC Member States and Austria.

The aims of the project were to assess the trade in selected wild-collected plant species in Europe in order to develop appropriate means to improve controls and to increase the general awareness of plant trade issues among government authorities and the general public.

The results of the study (The wild plant trade in Europe: Results of a survey of European Nurseries published by TRAFFIC Europe, 1992) demonstrated conclusively that trade in wild-collected plants still persists within Europe. This trade fell under three categories: mass importation of some species for the general or 'supermarket' trade; importation of prestige 'specimen' plants for the non-specialist trade; and importation of plants for the specialist collector. Detailed information collected during the survey regarding individual plant groups is incorporated into the species sections of the present text.

Germany remains the largest specialist market for cacti and other succulents and there is still a significant demand for wild-collected plants. There are two major importers of wildcollected succulents from Madagascar and South Africa, which sell directly to the public and supply other European nurseries. In recent years Italy has become an important market for specialist cacti and succulents with ten nurseries selling significant quantities of wild plants. Italian dealers apparently obtain these plants from a wide variety of sources both directly from the countries of origin and via countries such as Austria, Germany and the Netherlands. 
The UK was historically the centre of the European orchid trade. It still has a relatively large number of orchid nurseries, around 30, but these do not appear to deal in large numbers of wild plants. France also has a long tradition of orchid cultivation and trade. Several nurseries offer large quantities of wild species of native and tropical origin. However, most of the traders who specialise in the importation of both propagated and wild orchids are based in the Netherlands and to a lesser extent in Germany. Dutch orchid nurseries are known to import from Australia, Indonesia, Thailand, Brazil, Ghana, Honduras, Costa Rica, Hong Kong, Suriname and Mexico. It is believed that increasingly imports come via other European countries, chiefly Belgium and France, where import controls are less strict. As with succulents, Germany has the largest market for species orchids.

The bulb trade, which involves literally tens of millions of wild-collected plants each year, is centred on the Netherlands with most plants originating in Turkey, although significant numbers are also collected within EC countries, including Portugal, France, the Netherlands and the UK. Bulbs routed via the Netherlands are exported to overseas markets, chiefly in North America, as well as being sold within the EC.

Significant trade in wild-collected plants also occurs in air plants (Tillandsia spp.), cycads and some carnivorous plants.

Recommendations arising from the survey address:

- the need to harmonise legislation within the EC;

- the development of training programmes for enforcement officers;

- the establishment of a nursery registration system for establishments dealing in CITESlisted plants;

- the need to collect information on the status of wild plant populations still subject to direct exploitation;

- a proposal to carry out a comprehensive review of plant listings under CITES and present and proposed EC wildlife trade legislation;

- the encouragement of links between botanical gardens and the horticultural trade. 


\section{INTRODUCTION}

"If you want to be happy for a week, take a spouse; if you want to be happy

for a month, kill a pig; if you want to be happy for life, make a garden".

So runs an old Chinese proverb. The first two statements may be open to dispute, but more and more people are taking up the last of these suggestions. Gardening as an occupation has shown unprecedented growth in Europe over the past decade with, for example, over half the adult UK population now said to use garden centres.

Meeting this demand has turned horticulture into big business within the EC. Europe has been a major centre for horticultural development and the plant trade for centuries. There has been a strong tradition of plant exploration - and some would say the plundering of plant resources - in the past linked with the processes of colonisation. Formerly the preserve of the wealthy, gardening for pleasure and the enjoyment of house plants are now available to all. To supply the expanding market, the Dutch plant and cut-flower trade, admittedly the biggest in the world, is now worth US\$2.4 billion a year. The number of plants involved is enormous, with the Dutch aione producing, for example, a staggering one billion chrysanthemums each year.

The horticultural trade is not, however, just about the production of millions of uniform plants - not only are more people gardening than ever before, but the depth of interest has intensified, with gardeners demanding an ever wider range of plants to grow. This is nowhere better exemplified than in the success of the Plantfinder books, now produced in the UK, France, Germany and Switzerland. The UK Plantfinder alone lists over 55,000 plants commercially obtainable in nurseries in Britain and Ireland.

Ultimately, all these garden plants can trace their ancestry back to the wild. Some have been so transformed by centuries of cultivation and hybridisation that their origin remains a matter of speculation. Others remain close in appearance to their original wild relatives. The great majority of garden plants are available in commerce as artificially propagated plants raised in nurseries by a variety of methods - from seed, by division, cuttings, layers, grafting or, increasingly, by sophisticated micropropagation or tissue culture techniques. A surprising number of plants, however, still find their way into cultivation directly from the wild. These are collected by amateurs for their own purposes or by collectors to supply the commercial trade.

Most EC countries have legislation protecting native wild plants and commercial collection of attractive species is largely restricted. A wide range of horticultural plants is however imported from the wild from various countries around the world - as are other wild plant products such as timber, aromatics, medicinal plants and herbs. This trade has significant implications for the management and conservation of wild plants and their habitats. 
The scale of the trade in horticultural plants from the wild varies enormously from species to species, and so does its impact on wild populations. It may involve a mere handful of plants sold by a specialist, or it may involve millions of plants aimed at the mass market. One of the major problems with this trade is that it is largely unmanaged and unmonitored and it is therefore very difficult to assess its extent and the overall impact it has. However we do know that some of the trade is illegal, and much of it is damaging to wild plant populations, some of it extremely so. There are instances of plants having been driven virtually to extinction in the wild through the attentions of collectors.

The difficulty for the gardener with a conscience lies in knowing which of the tens of thousands of plants commercially available may have been wild collected, and further in knowing which of these are under pressure in the wild.

\section{Why are wild plants collected for cultivation and international trade?}

Wild plants are brought into cultivation for a variety of reasons. First is the constant search for novelty - horticulturists have essentially two sources of new plants: they may produce them themselves - through raising hybrids or selecting particularly desirable sorts or forms of plants already in cultivation - or they may look to the wild. The heyday of collection of new plants for cultivation was in the late 19 th and early 20 th century but this activity still continues on a smaller scale and many admirable garden plants are quite recent arrivals in cultivation. There is for example growing interest in the bulb floras of South Africa and South America, with new species continually appearing in Europe. Responsible collection of small quantities of wild stock (preferably as seed or other propagules) for propagative purposes should do no harm to wild plant populations. Bulk collection of seed to supply the demand for wildflower seed is however a separate issue - and one which is causing increasing concern to conservationists.

The second reason wild plants are grown in the gardens and greenhouses of Europe is the straightforward desire to own wild specimens, prevalent still amongst a small number of specialist collectors, especially of cacti and orchids. Wild-collected plants, of known source, are considered to have more allure and prestige than artificially propagated plants of the same species. Some amateur collectors have made an important contribution to the scientific study of plant groups. Others are motivated purely by the desire to own a complete collection with rare and hard-to-obtain species a particular attraction. Enthusiasts may derive particular pleasure from collecting plants themselves, but failing this they will pay premium prices to dealers for rarities even if artificially propagated plants of the same species are readily available. Newly discovered species in the wild are particularly vulnerable to collecting pressures.

From a broader trade perspective, wild plants are brought into cultivation because wellestablished trade patterns and practices within the European market are slow to change. Where there has been a ready - and seemingly endless - wild source of suitable plants, such as the natural bulbfields of Turkey, with collectors, agents and transport arrangements in place, the trade has continued unquestioned until recent years. And no doubt the most 
important reason why wild plants are traded is that more profit can be made from importing and selling wild plants of certain species than producing them in European nurseries.

People who collect wild plants for the commercial trade are usually paid very low rates compared to the selling prices in European garden centres and nurseries. This income may nevertheless be an important supplement to peasant wages in Turkey, Madagascar or Mexico — a fact sometimes used to justify the wild plant trade.

For plants entering the international market, important requirements are suitability as house and garden plants and ease and cost of transport. It is no coincidence that the majority of wild plants in trade are those which are resistant to desiccation and which can be easily transported in bulk and without soil. These include bulbs, corms and tubers, many orchids, cacti and other succulents. Because of their particular characteristics many of these species are well-suited to modern centrally-heated homes - a factor which accounts for their continuing popularity. In addition most of them are small, so that transport costs per individual plant are kept low. For the import of large plants to be economically viable, they must be able to command premium prices to cover transportation costs - as well as being able to withstand long periods out of the ground. Examples include cycads, some large succulents such as Yucca rostrata, and cacti such as the Saguaro Carnegea gigantea and barrel cacti of the genera Ferocactus and Echinocactus. Specimen plants of this kind may fetch prices of hundreds, or even thousands, of pounds in European trade - mainly for display in atriums of corporate office buildings.

For some species, wild-collection continues because artificial propagation is difficult or because plants take several years to reach saleable size, or often for both reasons. Maintaining stock in a nursery for long periods before sale is invariably expensive, and may often raise prices higher than consumers are prepared to pay. This is the case with the slowgrowing 'air-plant' tillandsias and with many species which produce corms or tubers such as the wake-robins Trillium spp. and Arisaema species which may take seven or eight years to reach flowering size from seed. Many orchids are both difficult to propagate and take many years to reach flowering size. As a result, large numbers of species appear in trade as wildcollected plants.

Demand also persists for wild plants of slow-growing species of cacti and other succulents. These are usually the more difficult species which appeal to specialist collectors, such as the Mexican cacti in the genera Ariocarpus, Aztekium or Pelecyphora. The majority of cacti and succulent species in trade are however easy to propagate and reach saleable size quite quickly, either under glass in the Netherlands and elsewhere in northern Europe or in open air nurseries in the Mediterranean region and the Canary Islands. For commonly propagated species there is no incentive to import wild plants. 


\section{The effects of wild collection on plants}

Plant species worldwide face an increasing barrage of threats to their survival. Chief amongst these is the destruction and degradation of their habitats by agriculture, industry or housing development, and pressures from pollution and climatic change. Introduced animals such as rabbits, goats and pigs have devastated island floras which evolved for millennia in the absence of grazing animals and thus had evolved no defences against them. In many countries introduced weeds - often introduced as consequence of trade in garden plants have squeezed out less competitive native species. The World Conservation Monitoring Centre estimates that as many as 25,000 species, or $10 \%$ of the world's flora, are currently under some degree of threat. At least 650 plant species are recorded to have become extinct in historical times and many more are likely to have been lost before they were known to science, in botanically underexplored parts of the tropics.

In comparison with these other threats, collecting for the horticultural trade might seem of minor importance, but this is often far from the case. While it is true that collection of plants such as common snowdrops, cyclamen and tillandsias is unlikely ever to result in the extinction of the species concerned, it may lead to their disappearing entirely from significant portions of their range. This results in the loss of valuable genetic resources which could be used in plant breeding as well as marked impoverishment of the environment. Large-scale trade may also inadvertently damage populations of much rarer, more vulnerable species, as occurred when corms of the rare Cyclamen mirabile were accidentally collected and included in consignments of the common Cyclamen coum exported from Turkey.

However, it is the deliberate collection of rare plants which poses a far greater threat to wild plant species. Specialist collectors actively seek out the rare, the new and the exotic and are therefore often particularly attracted to plants which are naturally uncommon and localized. These are precisely the plants which are least capable of sustaining any heavy harvest from the wild - species as diverse as the Mexican cactus Ariocarpus agavoides, the South Indian lady's slipper orchid Paphiopedilum druryi and the giant pitcher plant Nepenthes rajah, all naturally localized species, have been driven to extinction or near extinction by avaricious collectors.

Some growers delude themselves into thinking that they are playing a positive role in conservation by buying and attempting to grow wild plants of rare species, on the grounds that these plants were likely to be doomed in the wild. However this argument is often selfdefeating as for the plants in question frequently the major threat is collection for trade! This is the case with many of the South-east Asian lady's slipper orchids which were plundered from national parks where their habitat was perfectly secure. Organized salvage can be a useful conservation measure, but the plants which appear in commercial trade are rarely a result of such activities.

The artificial propagation and distribution in cultivation of threatened plants can certainly be a useful insurance policy in preventing species from becoming completely extinct. Indeed 
several plants now widespread in cultivation, such as the North American Franklin Tree Franklinia alatanaha, the Vietnamese slipper orchid Paphiopedilum delenatii and the Chilean bulb Tecophilaea cyanocrocus, are now extinct or probably extinct in the wild. However it is surely always preferable to maintain species in the wild state if this can be done. This means placing as little pressure as possible on wild populations of rare and threatened species.

If properly managed, wild plant populations could provide a sustainable source of income and provide an incentive to maintain natural habitats. Unfortunately proven examples for the horticultural trade are difficult to find.

\section{Attempts to control the collection of plants}

The harmful effects of over-collection of wild plants have long been recognized. As early as 1911 the Swiss canton of Zug enacted legislation banning the collection of some spectacular alpine plants such as lilies and edelweiss. Germany has had similar legislation since 1936, while Mexico has banned the export of native wild plants for over fifty years. Other countries have been slower to follow suit but many have passed laws in the last ten or fifteen years to protect at least some of their flora.

Most of this legislation prohibits the uprooting or destruction of particular species of wild plant but some of it extends as far as banning the picking of flowers. Lack of awareness and indifference to the laws hinder implementation and it is usually difficult to prevent landowners from digging up or destroying plants on their land. Nevertheless national measures can be reinforced by international cooperation particularly where species are under threat because of international commercial demand.

\section{Cites}

The principal means through which international trade in plants is controlled is the Convention on International Trade in Endangered Species of Wild Fauna and Flora (CITES), sometimes known as the Washington Convention. This convention first came into force in 1976 and has now grown to become one of the largest and best known of all conservation conventions, with 116 member states (in October 1992). Its aim is to regulate trade in threatened wild animal and plant species and the method by which it sets out to do this is to list such species in three appendices. Species listed in Appendix I of CITES are considered severely threatened by trade and all commercial trade in wild specimens between countries who are members of the convention is banned although import and export for scientific purposes may be permitted. Species listed in Appendix II of the Convention are those which may be threatened by excessive levels of trade without appropriate regulation. Species may also be included in Appendix II because of their similarity to more threatened species, as an aid to enforcement. Commercial trade in wild specimens of Appendix-II species is permitted under the convention but is controlled and monitored through a licensing system. Appendix III is used by countries which may want to control trade in particular members of their own flora and fauna which are not listed on the other Appendices. 
Plant and animal species are added to or removed from the various Appendices by agreement of the member states. Normally these changes are made at the Conference of the Parties which is held every two years, but changes may also be made through postal votes between the meetings.

Details of the plants listed in the Appendices are given in Annex I. At present some 200 plant species are listed in Appendix I of CITES. Although there are some timber species, such as the South American Alerce Fitzroya cupressoides, the great majority of them are plants which may be under threat from collecting for horticulture - mostly orchids, cacti and cycads.

A far larger number of species is listed in Appendix II of CITES although no-one can say exactly how many. This is because the entire orchid family is listed in the Appendix and botanists cannot agree how many species there are in this, the largest of all plant families. Estimates vary from 17,000 to 25,000 . Other families listed in their entirety include the cactus family, two families of cycads and two of tree ferns although all these are much smaller than the orchid family.

\section{Enforcement of CITES}

CITES was originally developed mainly with animals in mind and enforcement of the Convention for plants has sometimes proved problematic. A major problem is that of identification. Very few customs officers or other enforcement agents have specialist botanical training and even with such training it may be very difficult for them to distinguish. say, an Appendix- $\mathbf{I}$ listed orchid from one listed in Appendix II. In many ways a greater problem, however, is the existence in international trade of, literally, tens of millions of artificially propagated plants of both non-CITES and CITES-listed species, including large numbers of those in Appendix I. This trade is perfectly legitimate and is not harmful to wild populations of the plants concemed. Indeed it may be positively beneficial in helping to stem demand for wild plants. Allowing this trade to continue in as unhampered a way as possible, while at the same time keeping tight control on the trade in wild plants has often proved a difficult balancing act

Several efforts have been made to streamline the operation of CITES. Seeds, tissue cultures, and flasked seedlings are, for example, exempt from CITES Appendix II controls for most listed species, as are cut flowers of artificially propagated orchids. Additionally, in many countries artificially propagated Appendix-II plants are effectively treated as if they were not covered by CITES. This allows legitimate traders to carry out their business, but also leaves the system open to abuse as it is easy to mis-declare wild-collected plants as artificially propagated.

Whether it is by covert smuggling in suitcases or through the post, or through mis-declaration of openly imported shipments, there is no doubt that it is still possible, and sometimes relatively easy, to import wild plants in contravention of CITES. Surveys conducted by TRAFFIC in Europe and Japan in the past few years have revealed the widespread and often open availability of Appendix-I listed wild plants in nurseries. 
With limited manpower, enforcement officers cannot hope to inspect all shipments of plants in detail and thus wild-collected plants can slip through. Even if shipments are inspected, it takes a practised eye to unequivocally distinguish wild-collected from artificially propagated plants. Thankfully, interest in plant trade issues has increased considerably in recent years. A major result of this has been the employment of a full-time plant trade officer at the CITES Secretariat (the Convention's coordinating body) which has done much to increase the level of awareness of plants in trade among those responsible for controlling wildlife shipments.

While enforcement, both within Europe and in many countries of origin, has improved considerably in the past four or five years, it is only through changing demand that illegal and unsustainable trade will ever be stopped. This means that active consumer choices can have a direct effect on the conservation of rare plants. There are encouraging signs that these changes are already occurring as more and more specialist collectors refuse to buy wildcollected plants.

\section{EC CITES Regulation}

In EC countries, CITES controls are implemented by means of Council Regulation 3626/82, which came into force on 1 January 1984. This Regulation goes beyond the basic requirements of CITES by imposing the necessity for import, as well as export permits, for CITES Appendices II and III species brought into the Community. Furthermore it imposes stricter conditions for the import of certain Appendix-II species than would be required under the Convention. Under the Regulation all orchid and cyclamen species native to EC countries are treated as if they were listed in Appendix I of CITES. Intra-community trade in these species and all Appendix-I plants is generally prohibited, unless specifically allowed under license.

As both a major consumer of wild plants for horticulture and a major producer of artificially propagated CITES species for export, it is important that the EC has effective means to implement the Convention. Inconsistencies remain in enforcement provisions, with some countries operating very lax controls on the plant trade.

In order to improve implementation the EC CITES Regulation has been subject to extensive review and a revised version has been prepared. The proposed replacement for Regulation $3626 / 82$, is being considered by each Member State. Initially the revised Regulation was planned to enter into force on 1 January 1993, to coincide with the formal completion of the single European market, but entry into force in mid-1993 at the earliest is a more realistic estimate.

It is proposed that when the new EC Iegislation comes into force, as well as all CITES-listed species, a significant number of other plant species will also be subject to trade controls. The strictest degree of control is for example proposed for eleven Narcissus spp., ten other bulb species, a range of ferns, alpine plants and European rarities. A new provision of the legislation would be to introduce a list of plants (and animals) for which import into the EC would be monitored through a declaration system, without a specific requirement for export 
documentation. The intention is to build up a clearer picture of the quantities of listed species entering the Community to provide an early warning system of potential trade threats. Bulbs, succulents, carnivorous plants and timber species are included in the proposed list. 


\section{SPECIES REVIEWS}

The following sections review trade in orchids, bulbs, cycads, palms and tree ferns, cacti and other succulent plants, carnivorous plants and air plants. These are the groups for which we know there is significant international trade in Europe in wild plants. Trade, or at least collection from the wild, certainly occurs in other groups such as water plants and alpines. Very little is known about this trade, although most of it appears to be on a local, amateur or semi-amateur basis rather than as an organised professional enterprise.

For the groups we have covered, as well as outlining the trade, we have given some pointers to help would-be purchasers to decide what the likelihood of a given plant being wildcollected is, and, if so, whether they are likely to be damaging wild populations by buying it. In general, we have advised against buying wild-collected plants as there are as yet too few cases where sustainable harvest from the wild can be demonstrated. In the case of CITES Appendix-I listed plants, we have emphasised as strongly as possible the importance of not buying wild-collected plants. Not only will these have been illegally imported, but buying them will be driving an already threatened species closer to extinction.

\section{ORCHIDS}

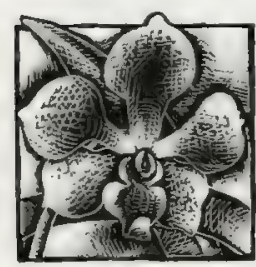

Orchids are widely considered to be the aristocrats of the plant world. This enormous, cosmopolitan, group, by far the largest of all plant families, contains an astonishing diversity of plants whose spectacular, sometimes almost sinister, beauty and exotic aura have long beguiled laymen and experts alike. Their cultivation, until recently, has been seen as the preserve of the specialist, with orchid growers themselves having almost as exotic a reputation as the plants they grow.

\section{Tropical orchids}

Exotic orchids have been grown in Europe since the 17th century, although large-scale cultivation did not begin until the 19th century. The latter half of the 19th century was a period of intense activity in orchid growing in Europe, particularly in the United Kingdom where it was concentrated, and enormous quantities of wild plants were collected for import by the major firms of the day, many of whom had professional collectors operating in various parts of the tropics. Rivalry between collectors and firms was often intense, and the trade was fuelled by an apparently insatiable demand for new species and varieties, which continued to be discovered in large numbers. By the early part of the twentieth century, many of the more accessible sites for orchids had been virtually collected out, and the supply of novelties largely dried up.

Nowadays the vast majority of orchids grown in Europe are hybrids, artificially propagated in massive numbers under laboratory conditions and grown on in greenhouses. Most of these are destined for the cut-flower trade, but increasingly plants are offered for sale in florists, garden-centres and supermarkets. There has been a realisation that many orchids are 
no harder to grow in the home than other house plants, and mass-production is bringing prices down to an affordable level.

Nevertheless there still remains a flourishing specialist market for orchids, with many thousand amateur orchid collectors in Europe, a small minority of whom are prepared to go to almost any lengths to obtain particularly desirable plants. A large proportion of orchid collectors grow mainly hybrids, but many include some species or 'botanical' orchids, as they are commonly known, in their collections, and a number specialise in these. This market still supports an extensive trade in wild-collected plants, most of them originating in Central and South America, Southeast Asia, India and Madagascar.

Like all hobbies, orchid-growing is susceptible to the vagaries of fashion, and groups of plants change in their popularity. Often the production of a major monograph on a particular group of orchids, or orchids from one country, will stimulate interest in those species and encourage collectors to set off in pursuit of the plants in the wild. Sometimes it is the discovery of new species which triggers off renewed interest in a particular group. This was the case with the South-east Asian lady's slipper orchids Paphiopedilum.

There are between 60 and 70 species of Paphiopedilum scattered through eastern Asia from south India as far as New Guinea and the Solomon Islands. Many of the species are very localized, often occurring on only a few limestone outcrops in jungle areas. Paphiopedilum orchids have been ardently collected for over 150 years. Indeed at the turn of the century they were the most popular of all orchid genera in Europe. Their popularity subsequently waned, but they nevertheless remained widely cultivated both as species and as hybrids. In the 1960 s a new species, $P$. sukhakulii, was discovered in Thailand. Its import into Europe in vast quantities - all wild collected - led to the entire genus suddenly becoming fashionable in collections once again. The discovery of $P$. sukhakulii was followed by that of a number of other new species, sustaining the interest of collectors and fuelling the trade in wild-collected plants. A particularly telling example of the destructiveness of this trade was not in fact a new discovery, but rather the rediscovery of a species feared extinct. This was the small, pretty Paphiopedilum druryi from southern India which had not been seen in the wild for many decades. In 1972 a new colony was discovered; almost immediately commercial collectors descended and over 3000 plants were stripped from the site, effectively wiping out the colony. When Indian officials visited the site a few years later, they could find only three plants, which they took into safe keeping, with the result that the species apparently became extinct once more in the wild. Since then the species has been rediscovered yet again but its existence in the wild remains precarious and it is permanently vulnerable to unscrupulous collectors.

These discoveries kept attention focused on the genus, but Paphiopedilum did not truly gain centre stage in the orchid world until the 1980 s when a series of sensational new discoveries was made in south-west China, including the bright yellow Paphiopedilum armeniacum and the huge-flowered pink and white $P$. micranthum. The demand for these new plants was intense, and enormous numbers were exported from China, mostly via Hong Kong, to feed 
the markets in Europe, North America and Japan. All the plants were wild-collected and it seemed very unlikely that the wild populations could cope with this level of offtake.

It was not just these new species which suffered from the attentions of orchid hunters. Several well known species, particularly in Borneo, have had populations ravaged despite the best attempts of governments to protect them. These include the fabled Paphiopedilum rothschildianum, the most spectacular of all slipper orchids, known only from Mt Kinabalu National Park in Sabah, and the extraordinary Paphiopedilum sanderianum from Gunung Mulu National Park in Sarawak, which has twisted ribbon-like petals which may reach $90 \mathrm{~cm}$ in length. Plants of the former, stolen from the park, were offered for sale in the USA. for a staggering $\$ 5000$ apiece in the late 1980 s. $P$. sanderianum had not been recorded since the 19 th century before the 1980 s when it was rediscovered by botanists working in Sarawak. Unfortunately a team of persistent commercial collectors discovered the location of the wild populations and in 1986 plants turned up on the American market priced at \$1,500 per growth.

Although most Paphiopedilum plants are worth far less than this, these prices demonstrate just how much fanatical hobbyists are prepared to pay for exceptional plants and the strong incentives for collectors to ureak the law. There are even tales of collectors destroying wild plants surplus to their own requirements to prevent rivals obtaining them.

In an attempt to control this increasingly damaging trade, the entire genus Paphiopedilum was placed on Appendix I of CITES in January 1990. This has certainly helped to cut down the trade, but has by no means eliminated it. In 1991 the TRAFFIC investigation discovered a consignment of 500 wild-collected Philippines Paphiopedilum species, including the rare $P$. haynaldianum, on sale in a French nursery. Ironically, this was the very nursery which had played an instrumental part in the 1920s in ensuring the survival in cultivation of the Vietnamese $P$. delenatii, a species believed possibly extinct in the wild.

A similar, though less marked phenomenon, occurred with the closely-related South American slipper orchids in the genus Phragmipedium. In the late 1970s a remarkable new species, Phragmipedium besseae, with beautiful orange-red flowers was discovered in Ecuador. Large numbers of wild-collected plants quickly found their way onto the market, fetching high sums. Again concern was felt that wild populations of this and some of the other rare Phragmipedium species could not support such indiscriminate harvest and to safeguard them, the entire genus was placed on Appendix I of CITES, also in 1990.

Interestingly the discovery of $P$. besseae does not appear to have sparked off a resurgence in interest in Europe in the other Phragmipedium species to the same extent as has happened with Paphiopedilum. In general they are relatively little grown here although they remain popular in the USA. P. besseae itself is definitely still much in demand and although most specimens were imported before the CITES ban came into effect, wild plants are still illegally - entering Europe to the detriment of wild populations. 
Other groups which are popular at present include the South and Central American Masdevallias and their allies and the New Guinea species of the genus Dendrobium, one of the largest of all orchid genera. The former are small to medium-sized plants which require rather different growing conditions from the majority of orchids. Collectors who grow them tend to specialize in them and attempt to acquire as many species as possible. Some dealers offer as many as 50 species, many of them as wild imports. One species, Dracula vampira, with bizarre, pendant flowers, is one of the most sought-after of all orchids at present, and is almost certainly imported from the wild to meet the demand. Unfortunately there is very little information on the status of most of these species in the wild, and so it is difficult to tell what impact the trade is having on wild populations.

Much of the trade in wild plants is still permitted under CITES, but an increasing number of countries have banned all commercial export of wild-collected orchids under their own national legislation. These include India, Indonesia, Sri Lanka, Papua New Guinea, Costa Rica, Honduras and Peru.

Until 1991, Thailand was by far the largest supplier to Europe of wild-collected orchids, many of them originating in neighbouring countries and a considerable proportion illegally collected. In 1991, however, as a result of the continuing trade in illegal wildlife from Thailand and partially as a result of a TRAFFIC investigation, it was recommended by the CITES Standing Committee (the Convention's executive body) that member countries ban import of all CITES-listed species from Thailand. This led to a surge of imports of orchids from Thailand before the ban was imposed — one Dutch nursery alone reputedly imported 20,000 plants in one consignment in spring 1991. The international ban on Thai wildlife products was lifted in 1992 following the introduction of national legislation. In order to control the orchid trade the import or export from Thailand of orchid species is forbidden, except under permit, and artificially propagated plants must be produced in registered nurseries.

In general, the increasing difficulty of obtaining wild-collected plants legitimately has induced more and more orchid nurserymen to start artificially propagating their own stock. Artificial propagation of orchids can be a time-consuming and complex affair, especially raising from seed, which generally requires sterile laboratory conditions. For some species, such as many paphiopedilums, the seed pod may take as long as eighteen months to ripen and the plants may not flower until six or seven years after germination. All this helps to explain why wild-collected plants have remained in demand - it is far cheaper to import mature, flowering-sized plants from the wild than it is to grow up plants for sale. However, even if conservation arguments are disregarded, the growing of wild plants has its drawbacks mortality rates amongst imported plants are often very high and even if plants do survive they will often take many months or even years to recover from the shock of transplanting and long-distance transport and begin growth. Furthermore, they often simply do not grow as well in cultivation as artificially propagated stock does. 
As artificial propagation of orchid species becomes more widespread, plants will become cheaper to buy - indeed some conservation-minded nurserymen have the intention of flooding the market with cheap seedlings of rare species, thereby undercutting the demand for wild imports. It is now possible to buy seedlings of Paphiopedilum rothschildianum for $£ 10$-£12 and one enterprising UK firm offers seedlings in flasks of around 40 Paphiopedilum species, including many of the rarest. These require some patience on the part of the purchaser to grow on to flowering size, but are ultimately arguably far more rewarding than wild plants. In an effort to encourage the trend to artificially propagated plants, the European Orchid Committee has produced a catalogue of orchid species which can be obtained as nursery-raised stock (Beguin, 1992).

\section{Hardy orchids}

With the burgeoning interest in wild-flower gardening, hardy orchid species have become popular and desirable plants with collectors. Unfortunately, artificial propagation of these species has often proved difficult and has not kept pace with the demand. A large proportion of plants in cultivation have, at least until very recently, been of wild origin. In the UK wardening schemes are necessary to protect rare and attractive orchids within nature reserves. Nevertheless thefts continue, driven by commercial demand. In one recent case 100 green winged orchids Orchis morio were stolen overnight from a reserve. Hardy orchids are also imported from eastern European countries, North America and temperate Asia.

Pre-eminent amongst them are the Lady's Slipper Orchids in the genus Cypripedium, closely related to the tropical slipper orchids in the genera Paphiopedilum, Phragmipedium and Selenipedium. There are around thirty-five members of the genus, of which the most famous in Europe is undoubtedly the native Cypripedium calceolus. This beautiful plant, which is found across the Northern Hemisphere in Europe, Asia and North America, has been coveted by gardeners since Victorian times, much to the detriment of wild populations - the British population has been reduced to a mere handful of plants, whose precise location is a closelyguarded secret. Cypripedium calceolus is extinct in Belgium and Luxembourg and is considered to be Vulnerable throughout Europe.

Cypripedium calceolus, like other temperate slipper orchids, is difficult to propagate artificially, and is not easy to maintain in cultivation. There is thus a continuing demand for wild plants which continue to be dug up, both by amateurs for their own collections, and by commercial dealers, despite it being legally protected in most of Europe by national legislation and, along with all other native orchid species, receiving special protection under the EEC wildlife trade regulation. Collectors are now tuming their attentions to the eastern European countries - in 1990 it was reported that large colonies of the orchid in Czechoslovakia, previously protected through being in military areas, had been destroyed almost overnight.

Other species which are relatively widely available include the Asian species Cypripedium japonicum (often sold as C. formosanum) and C. macranthum, the North American Moccasin Flower C. acaule and the Queen Lady's Slipper C. reginae. The first of these is 
apparently artificially propagated in quite large numbers in the Far East, although it is likely that wild plants enter trade. The North American species have been imported into Europe in substantial quantities, almost entirely as wild-collected plants. In 1991, a British dealer was fined $£ 200$ for importing a consignment of North American slipper orchids and wake robins Trillium spp. without a license and in 1990 a large consignment of illegally imported Asian Cypripedium species was seized in Germany.

The Cypripedium species which occur most frequently in trade are in general still quite widespread and not imminently threatened with extinction, although some of them, such as Cypripedium calceolus may be seriously reduced in a large part of their range. There are several other species, however, in North America and Asia which are apparently rare and localised. These species are assiduously sought-after by specialists and collection of plants is likely to be having a serious effect on wild populations. Some of these species may even have been inadvertently collected for export, being mistaken for commoner forms: the German consignment seized in 1990 tumed out to include plants of $C$. farreri which had not been seen in cultivation for decades.

Lady's Slipper Orchids are by no means the only hardy orchids sold in Europe. The most widely-available and cheapest species is the easy-to-grow Bletilla striata from China and Japan which is imported in large numbers from the Far East. This plant is easy to propagate, and most of the plants offered for sale are artificially propagated, although some concern has been expressed that wild plants are entering the market. Also popular, although more doubtfully hardy, are the Asian orchids in the genus Pleione. These grow quite rapidly and are also relatively easily propagated by seed or by division. Again most of the plants sold are nursery-raised, although there is believed to be some collection of wild plants for export. There is also a strong specialist interest in pleiones and some of the rarer species have definitely appeared in the trade as wild-collected plants.

Many of the other hardy orchids are notoriously difficult to grow in cultivation. These include the European Ophrys species with their jewel-like insect-mimicking flowers and the Lizard Orchid Himantoglossum hircinum. Plants dug up from the wild, either by amateurs for their own gardens, or by commercial suppliers, are almost invariably doomed to a short life in cultivation. Rather easier are some species of Dactylorhiza and Orchis. Several of these are now fairly widespread as garden plants and can be quite readily bought as nursery grown stock.

- In general, exotic orchids for sale in garden centres and high street shops are nurseryraised hybrids.

- A significant proportion of the botanical orchids offered for sale by specialist nurseries are wild-collected. Wherever possible encourage nursery propagation by requesting propagated plants.

- Never buy wild plants of CITES Appendix-I orchids. 
- Attractive hardy European orchids have declined through habitat destruction and overcollection. They are protected by law in most EC countries and are given strict protection under the EC CITES Regulation. Never dig up wild species and don't buy native species unless you are assured that these are artificially propagated. 


\section{BULBS}

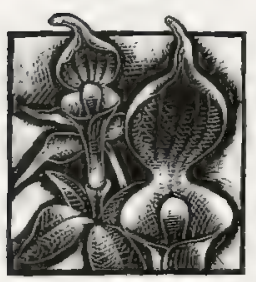

At the end of summer, choosing bulbs for spring planting, is a most pleasurable activity. But for gardeners with a green conscience a degree of caution is necessary. Most bulbs available in trade are produced in the extensive bulb fields of the Netherlands. Other EEC countries produce bulbs on a smaller scale, for example France, which has around 350 commercial bulb growers, and the UK which is the world leader in daffodil production. Some bulbs are, however, routinely collected from the wild for sale in garden centres, supermarkets and plant catalogues throughout Europe

The trade in wild bulbs has been largely hidden until recent years. Because of the complex chain from source to retail outlet few people realised that the bulbs they were buying or selling had been dug up from their natural habitats. Recent research by conservation organisations, including TRAFFIC, WWF, the World Conservation Monitoring Centre, the Flora and Fauna Preservation Society and Plantlife has revealed the true picture.

The main source of wild bulbs is Turkey. Every year millions of cyclamen, snowdrops, snowflakes, anemones and other bulbs are harvested from Turkey's rich natural bulb fields and exported to the Netherlands, the centre of the world's bulb trade, for packaging and distribution. The scale of the trade has worried Turkish botanists and a number of bulb species are now listed in the Turkish Red Data List.

International concern about the cyclamen trade led to the listing of this genus on Appendix II of CITES when the Convention first came into being. The EC has stricter import requirements under its CITES Regulation and there is now a quota system for cyclamen exported from Turkey. The UK-based Cyclamen Society advises its members not to buy wild cyclamen at all. The Society has been particularly concerned about the occurrence of tubers of rare species such as Cyclamen mirabile mixed in with consignments of more common species. The true identity of the plants is only revealed when they flower.

Snowdrops Galanthus, and the crocus-like Stembergia were added to CITES Appendix II in 1989. The most commonly cultivated snowdrop Galanthus nivalis occurs throughout Europe as a wild or naturalised plant. It was first introduced to the UK in Roman times. Now most of the plants in trade originate in the Loire valley in France, the Texel region of the Netherlands, Turkey and the UK. Most of the bulbs are harvested from semi-natural habitats such as old orchards or from wild populations in Turkey. Cultivation is, however, slowly increasing.

The main snowdrop species exported by Turkey is Galanthus elwesii. Around 15 million bulbs of $G$. elwesii are imported to the Netherlands from Turkey each year. Even though the species is quite widespread it is markedly affected by this scale of trade and in some areas populations have virtually disappeared. Cultivation has begun in Turkey, but so far this mainly consists of re-planting wild bulbs in fields and growing them on. Production of this bulb in the Netherlands remains tiny by comparison with imports from the wild. 


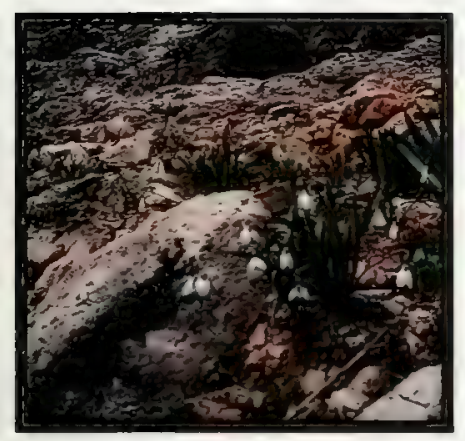

DID YOU KNOW? Millions of wild snowdrops from Turkey and wild air plants from Guatemala are sold in Europe each year. Most of the Venus fly-traps on sale in Europe were removed from the wild in the USA. Collectors will pay thousands of dollars for a single wild plant of some orchid species.

Gardening is one of the most popular and widespread of all pastimes and gardeners in Europe grow an enormous and ever-expanding range of plants. The great majority of plants available in commerce are artificially Trillum erectum propagated in nurseries. However, a surprising number still find their way into cultivation direct from the wild. This trade, along with that in other wild products such as timber, aromatics, medicinal plants and herbs, has significant implications for the management and conservation of wild plants and their habitats. Collection for commercial trade adds to the barrage of threats faced by wild plants around the world.

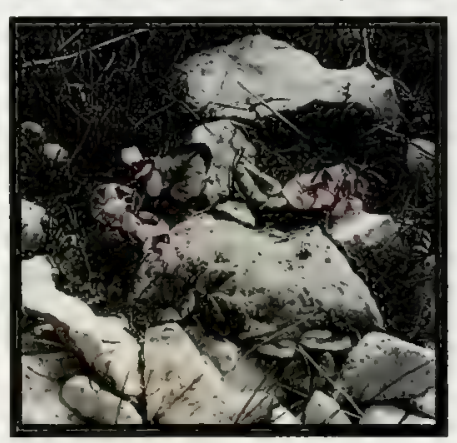




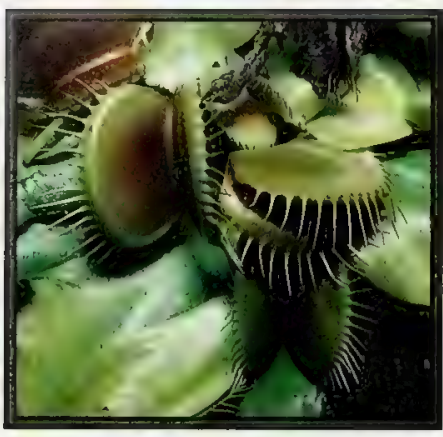

Dionaea muscipula
Commonly available plants which may have

been wild-collected include a variety of bulbs,

corms and tubers, air plants and Venus

fly-traps. On the Continent, a range of

cycads, cacti and other succulents also

appear in garden centres and other retail outlets. In the

specialist trade, a much wider range of wild plants,

especially orchids, cacti and succulents, is available.

- While collection of common and wide-

spread plants is unlikely ever to result in

the extinction of the species concerned,

it may still lead to their disappearing

entirely from significant portions of their

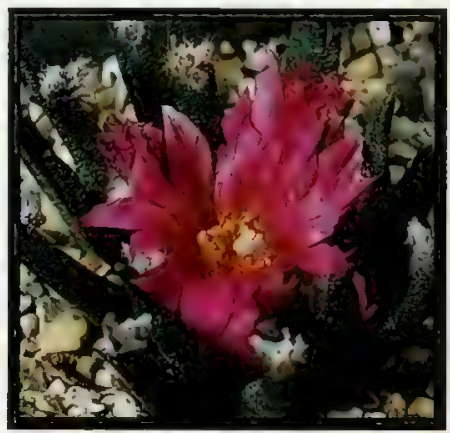

Ariocarpus agavordes

range. This would result in a marked

impoverishment of the environment as well as

the loss of valuable genetic resources which

could be used in plant breeding. However, it is

the deliberate collection of rare plants which poses

a far greater threat to wild plant species. Specialist

collectors actively seek out the rare, the new and

the exotic and are therefore often particularly

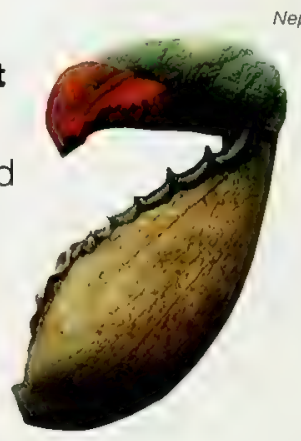




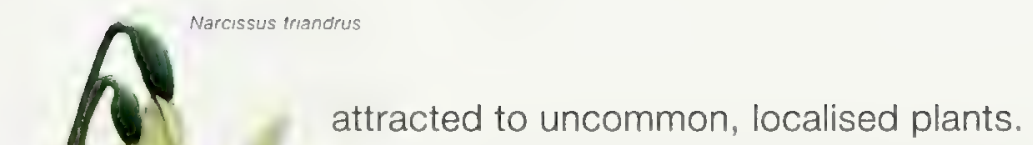

These are precisely the ones which are

least capable of sustaining any heavy

harvest from the wild. Species as diverse as the

Mexican living rock cactus Ariocarpus agavoides,

the South Indian lady's slipper orchid Paphiopedilum

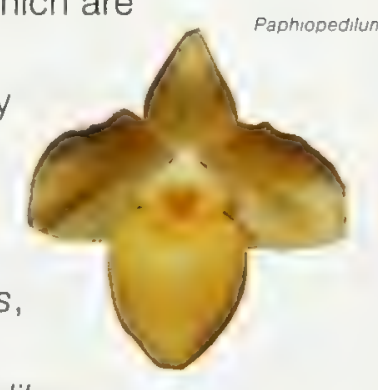

druryi and the giant pitcher plant Nepenthes rajah, all

naturally localised species, have been driven to the brink of

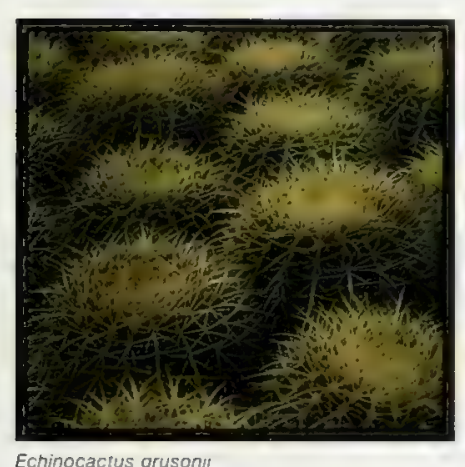

extinction by avaricious collectors.

Collectors will go to great lengths - and

pay enormous prices - to obtain

desirable plants. Many countries now

have legislation designed to protect

wild plants. Most of this legislation prohibits the uprooting

or destruction of particular species and some extends as

far as banning the picking of flowers. Unfortunately, lack

of awareness and indifference to the laws

undermines their effectiveness. Nevertheless,

national measures can be reinforced by inter-

national cooperation - particularly in relation

to commercial trade threats.

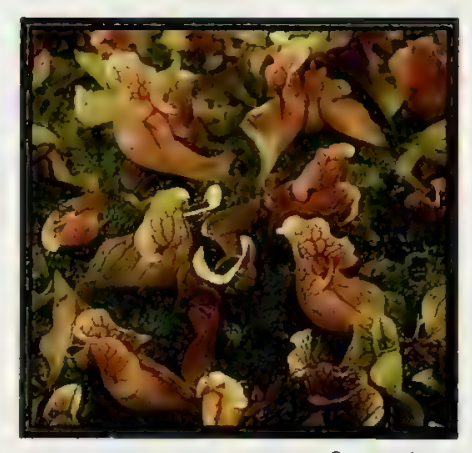

Sarracenia $\mathrm{sp}$ 
The principal means through which international trade in plants is controlled is the Convention on International Trade in Endangered Species of Wild Fauna and Flora - CITES. Its aim is to restrict or regulate trade in the threatened wild animal and plant species listed under the Convention.

Species in Appendix I of the Convention are subject to particularly strict control; whereas those in Appendix II can be more freely traded. In EC countries, CITES controls are implemented by means of Council Regulation $3626 / 82$, which came into force in 1984 . This Regulation is more strict than CITES in some respects and, for example, imposes a ban on commercial trade in all wild orchid and cyclamen species native to the EC. The Regulation is currently being revised and is likely to control a wider range of horticultural plants in the future. - While enforcement both within Europe and in many countries of origin has improved considerably in the past four or five years, it is only through changing demand that this trade will ever be stopped. This means that consumer choice can have a direct effect on the conservation of rare plants. 
The Turkish Government attempts to control the export of its bulbs by a system of quotas and bans on trade in rarer species, but commercial pressures are strong. The quota system has reduced export of Galanthus elwesii from over 30 million a year to 15 million. However. Turkey is not yet a member of CITES and this hinders international efforts to control the bulb trade. Nevertheless help is at hand locally to transform the trade. FFPS is running the Indigenous Propagation Project in conjunction with the Turkish Society for the Conservation of Nature and with funding from WWF. This project encourages villagers to grow bulbs on their own land for export so that they continue to receive a source of income without depleting wild populations. There is also a joint Dutch-Turkish trade project which should help regulate the trade.

Another source of wild bulbs is Portugal. Miniature daffodil species which are justifiably popular with gardeners are unfortunately supplied from the wild in Portugal. It is a sad reality that virtually all the small narcissi available from European suppliers are wildcollected and are harvested without management of the natural resource. There are no legal restrictions on collection except within protected areas and bulbs are known to have been taken from nature reserves. Around 200.000 wild bulbs of Narcissus triandrus var. triandrus, known in trade as 'Angel's Tears', are imported to the UK and the Netherlands from Portugal every year along with smaller numbers of other species and varieties. As a result of commercial collection and habitat destruction. ten taxa of Narcissus are considered to be threatened in Portugal and in need of legal protection. As yet there are no international trade controls to aid their survival but inclusion in the revised EEC wildlife trade regulation is proposed under conditions which would allow control of trade within the Community.

Wild bulbs are exported by a range of other countries including Hungary, Japan, UK and the USA. Trillium is the main genus exported by the USA. Although not strictly producing bulbs, trilliums are usually to be found in the bulb sections of garden centres and are listed in bulb catalogues. In the USA, trilliums, known as wake-robins, are amongst the most popular woodland wildflowers. Wild-collected rhizomes are offered for sale by roadside vendors and by nurseries and garden centres. Over 10,000 wild plants of Trillium spp. are exported from the USA to the Netherlands each year. Some UK nurseries propagate the trilliums they offer for sale but many also buy in plants from the Netherlands and USA. These are almost certainly wild-collected.

Collection of bulbs from natural habitats in the UK is known to occur but details remain hazy. The UK's native bulb flora consists of around 50 species many of which are naturalised or occur locally as garden escapes. Commercial collection concentrates on snowdrops Galanthus nivalis and bluebells Hyacinthoides non-scripta, both for the UK market and for export. The organisation Plantlife has been researching this trade recently and has found it to be much more extensive than first thought, forming a traditional source of rural income which may amount to $£ 1-£ 2$ million annually. Commercial bluebell diggers can strip entire woods and the bluebell populations may take decades to recover. Plantlife advises landowners to refuse permission when approached by bulb diggers and advises gardeners to check the origin of bluebells on sale. If the bulbs have not been 
collected from the wild this will usually be specified as a good selling point because nurseryraised bluebells are more vigorous, with erect stems and a slightly stronger flower colour.

Recognising whether or not bulbs on sale have been dug from the wild is becoming easier under a new labelling scheme introduced in the Netherlands. Since July 1990, all wildcollected bulbs sold by Dutch companies have been labelled as, "bulbs from wild source". Beginning in July 1992, all minor bulbs, that is all except the major field crops such as daffodils, tulip and hyacinths are labelled as either wild or cultivated. By 1995 all bulbs sold by Dutch companies will be labelled. This scheme has not yet been introduced in other countries but clearly needs to be expanded internationally.

In general it is not a good idea to buy wild bulbs when cultivated alternatives are available. Some growers are making great efforts to propagate rare and unusual species and their efforts are undermined by the import of cheaper wild-collected material. Collection from the wild is rarely adequately managed and places an unnecessary strain on wild populations. Furthermore cultivated bulbs provide better quality garden plants. When choosing bulbs remember:

- Most commercially available bulbs have been grown in nurseries or as field crops but if collected from the wild should be avoided.

- The following bulbs are likely to be wild-collected, so check the labelling and ask about the origin before you buy: Anemone blanda, Arisaema, Corydalis bulbosa, Cyclamen, Eranthis, Galanthus, Leucojum, Sternbergia, Trillium, miniature daffodils, bluebells.

- International trade in Cyclamen, Galanthus and Sternbergia is subject to CITES regulations.

- Most attractive species of bulbs are declining in the wild because of habitat destruction and rare species may be protected by national legislation. Don't dig from the wild. 


\section{CYCADS, PALMS AND TREE FERNS}

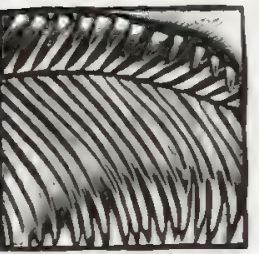

Cycads, palms and tree ferns offer a fascination and a challenge to the serious gardener. Few species are hardy in northern Europe and these plants are more usually associated with the elegant palm houses of botanic gardens. Nevertheless there is a growing collector interest within Europe and an increasing range of species is offered commercially.

Cycads, sometimes considered the dinosaurs of the plant world through having remained largely unchanged for tens of millions of years, are slow-growing relatives of the conifers. There are eleven genera with about 130 species of cycads found in Africa, Asia, Australia, the Western Pacific Islands, Florida, the Caribbean and Central and South America. Many species have low reproductive rates in the wild and limited natural distributions.

The consequences of habitat destruction and collecting pressures have been disastrous for cycads and over 50 species are Endangered or Vulnerable according to IUCN (The World Conservation Union) definitions. All cycads are covered by CITES controls but collecting pressures remain intense and smuggling of plants is known to take place.

Endangered plants of South African Encephalartos cycads in particular are immensely valuable on the world market and have been used as a means of smuggling financial resources out of the country. The conservation status of many species in the wild is now dismal. The last viable population of Encephalarios dolomiticus was for example collected to extinction during 1989. Fewer than twenty plants remain and there is no natural propagation. Other species endangered by collecting include $E$. eugene-maraisii, $E$. middelburgensis, $E$. dyerianus and $E$. cupidus.

Within Europe the cycad most commonly available is Cycas revoluta. Plants are nurseryraised from seed and are available as seedlings and pot plants. Larger specimen plants are imported from outside Europe, for example from Brazil, where they are reportedly collected from old estates. Species of Lepidozamia, Macrozamia, Dioon, Encephalartos and Zamia along with Cycas circinalis are relatively widely available, although in small quantities. The TRAFFIC Europe investigation of European nurseries showed that all Lepidozamia and Macrozamia appear to be artificially propagated but that some wild plants of Zamia and Dioon are offered for sale. Wild collected plants of Encephalartos are also sold in Italy and France, despite the fact that this genus is included in Appendix I of CITES.

Another group of plants grown mainly for their foliage is the palms. Like cycads, which they superficially resemble, palms are gaining in popularity throughout Europe. They provide fashionable corporate decor in new office blocks. Palms are readily grown from seed and nurseries mainly in the Netherlands, Spain and further afield in Malaysia and Sri Lanka, are increasing production to cope with the demand. Expansion of the trade is not without conservation problems. Collection of seed to supply the nurseries is harming the regeneration of certain palm species in the wild. 
One example is the Madagascan palm Neodypsis decaryi, which is now available from garden centres in Europe. This species is confined in the wild to a small area of about 5 sq.km in south-east Madagascar. Although the rare palm grows in a reserve, several hundred kilos of its seed are exported each year. Unfortunately the species is not suitable for growing indoors in centrally heated rooms, so buying the plants results in a continuous drain on seeds from the wild population.

Another group of palms in the genus Chamaedorea, favoured for their attractive leaves, is being exported in increasing quantities to Europe and the USA. The trade in this group and its implications for wild populations has been researched by WWF-US and its wildlife trade branch TRAFFIC-USA. They found that species such as Chamaedorea seifrizii and $C$. elegans, are widely cultivated from seed in Florida, Hawaii, Belize and Mexico, but the seed nearly all originates from the wild. A total of 25,000 kilos of seed of C.elegans enters Florida each year, along with 15,000 kilos of $C$. seifrizii. Both these species are available from specialist nurseries in Europe.

Vast quantities of Chamaedorea leaves are also imported to the USA, with for example 359,219,000 leaves imported from Costa Rica, Guatemala and Mexico in 1986, for use in floristry. TRAFFIC USA reports that in some parts of Guatemala leaf harvesting has reduced the Chamaedorea populations by as much as 75 per cent. At the same time excessive trampling in the forest by the estimated 6000 leaf harvesters is damaging small seedlings and young plants.

The European palm trade has not yet been thoroughly investigated and it is not known to what extent the trade has an impact on plant populations in the wild. It is unlikely that palms on sale in garden centres will be dug from the wild, but the examples given above show that some species are being severely affected by the trade.

There are around 650 species of tree ferns, in the families Cyatheaceae and Dicksoniaceae, which grow mainly in tropical regions of the world. Some species thrive in secondary forest, and are well-adapted to disturbance, but other species, mainly those which are confined to small areas, are under threat from deforestation and exploitation.

The main commercial value of tree ferns is from the use of trunk material as a horticultural growth medium. Tree fern species typically produce a mantle of adventitious fibrous roots which cover the narrow true stem. This material is sold as blocks, poles, containers, or in shredded fibrous form, and is specially favoured by orchid growers. Tree fern potting mix from New Zealand is being promoted by some traders as an environmentally acceptable alternative to the use of peat. New Zealand tree fern material largely originates in plantation or natural forests which are being logged for timber. As such it could be seen as a waste product of forestry operations and as long as the forests are effectively managed, production should be sustainable. There is, however, some concern about the declining availability of tree ferns within New Zealand's native forests. 
Dicksonia antarctica, the so-called hardy fern, is one of the few tree ferns which is truly hardy in Europe. It is imported commercially for sale as a garden plant. As with all other tree ferns, international trade in this attractive species is covered by CITES. Plants in international trade are felled in the wild and exported legally from Tasmania with CITES permits. As with New Zealand tree ferns. Tasmanian Dicksonia is a by-product of the logging industry. As long as the forests are properly managed and conserved it should be possible to supply plants to the horticultural trade on a sustainable basis.

- Cycas revoluta is by far the commonest cycad available; plants are either artificially propagated or imported from countries where they are naturalized.

- Other cycads available may well have been wild-collected; check their origin before you buy.

- Do not buy wild-collected Encephalartos plants as they will have been imported illegally.

- Palms on sale will almost certainly have been seed-raised in nurseries. Most species are not threatened; however, avoid buying the Madagascan Neodypsis decaryi for which seed-collection is an unnecessary drain on wild populations.

- If you buy large Dicksonia plants, check that they have been legally imported and are from a sustainable source. 


\section{CACTI AND SUCCULENT PLANTS}

Succulents are amongst our most commonly grown houseplants. The familiar prickly cacti, of the family Cactaceae, are perhaps the bestknown, but falling within the broader category of succulents are aloes, euphorbias, haworthias, kalanchoes, lithops and a whole host of other attractive and sometimes weird species. In total around ten thousand species of flowering plants are considered to be succulents in that they store water in their swollen stems or leaves. This adaptation, enhancing survival in arid natural habitats, provides a distinctive appearance which accounts for the horticultural appeal of succulents. Many million households in Europe will own one or two, often moribund, succulent plants.

The family Cactaceae consists of over 1500 species, virtually all of which are confined in the wild to the Americas. Considered to be symbolic of desert environments, nevertheless species also grow in alpine habitats and tropical rainforests. The centre of diversity of the family is Mexico, with over 800 taxa and home to some of the most popular species in trade.

Cacti have been known in Europe since the time of Columbus and have been widely grown in Europe for at least the past century. Commercial production is now on an enormous scale, running into tens of millions of plants each year. Nevertheless there has been a parallel demand for wild-collected plants and these remain too commonly available in trade.

Demand for cacti probably did not reach the same pitch as the nineteenth century orchid craze but avid collectors have long sought rare and unusual species. One specimen of the rare Ariocarpus kotschoubeyanus was sold in 1832 , by the collector Baron Wilhelm von Karwinsky, for 1000 francs, a price far exceeding the value of the plant's weight in gold.

The collection of wild plants of cacti and other succulent species has been a significant threat to the survival of wild populations. This is particularly the case with naturally rare and slowgrowing species such as the Ariocarpus or living rock cacti. A field survey carried out in Mexico in 1988 predicted that one species, Ariocarpus agavoides would be extinct in the wild within the next five years. A combination of threats has been responsible for the decline of the species since its discovery in 1941. Collecting for the European, Japanese and US market has certainly been a major threat with wild plants quite readily available in trade from specialist nurseries over the past ten years.

It has been estimated that around one-third of all Mexico's endemic cacti are threatened with extinction in the wild. There has been a legal ban on the export of wild-collected cacti from the country for the past fifty years but this has been too easily flouted as shown by nursery surveys. The situation should now improve since Mexico joined CITES in September 1991. At the international CITES meeting held in Kyoto, Japan in March 1992, the Mexican delegation reported that 18 foreigners were caught illegally collecting cacti in Mexico in 1991. In some cases these were "pseudo-conservationists" claiming to save wild plants. 
Madagascar is another country with a succulent plant flora in peril. Madagascar has an extraordinary range of succulent plants which matches in its diversity, endemism and fascination the island's unique fauna. Over 400 succulent plant taxa are endemic to the country including one entire family, the Didiereaceae, with plants which superficially resemble cacti. The conservation status of most of these plant taxa is unknown but pressures from habitat destruction and collection are strong.

Some Madagascan succulents are well-established in cultivation. Annual European production of the species Pachypodium geayi and $P$. lamerei, for example, amounts to well over a million plants. Other species have been routinely imported from the wild. Pachypodium brevicaule was for example imported in the tens of thousands from Madagascar to Germany in 1985 and 1986 and widely sold in general horticultural outlets. These plants were claimed to be artificially propagated but subsequent investigation has demonstrated that all were wild-collected. In the same way thousands of wild plants of the slow-growing species Euphorbia cap-saintmariensis, E. cylindrifolia, E. moratii, and E. primulifolia were imported into Europe in the mid-1980s, together with large numbers of Didierea and Alluaudia in the Didiereaceae. Unfortunately Madagascar does not have the resources to conserve or sustainably exploit its plant life. The development of commercial propagation facilities for succulent plants on the island could help to save species from extinction but has not yet taken place.

All species of the cactus family and a number of other succulent genera are listed on the Appendices of CITES. A range of the more vulnerable species is listed in Appendix I, so international commercial trade in wild plants is prohibited, although it continues to take place. The TRAFFIC Europe nursery survey revealed that wild plants of the Appendix I cacti Ariocarpus, Aztekium, Obregonia, Pelecyphora, and Strombocactus were all on sale in Italy. Wild Ariocarpus plants have been sold openly in the Amsterdam flower market, and nurseries in Belgium and Germany continue to stock Appendix I rarities. Early in 1992 seventy cacti including wild Ariocarpus and Strombocactus plants were seized from a shop in Paris. Nurseries no longer appear to stock Appendix I wild cacti in the UK, but the temptation remains for enthusiasts visiting the continent to pick up a few forbidden plants.

Other succulents do not yet enjoy international protection. They include many rarities native to Madagascar and South Africa - another major centre of succulent plant diversity. There is currently a fashion within the trade for caudiciform or swollen-stemmed plants, which occur in a wide range of families and genera. During the past decade caudiciform plants such as Kedrostris, Raphionacme, Cyphostemma, Dioscorea, Adenium and Fockea, none of which is listed under CITES, together with Pachypodium and caudiciform euhporbias have become popular houseplants. Many of these plants are slow-growing in cultivation and wild-collected plants are regularly offered.

Often it is impossible to assess what impact commercial collection is having on wild populations but given the declining habitats of succulent plants around the world it is generally difficult to justify the commercial collection, particularly when they can be cultivated. 
- Succulents are intriguing and rewarding house plants which account for a multi-million dollar industry. Although the majority of species on sale are nursery raised from seed and cuttings, others face extinction in the wild because of the continuing trade in habitat plants.

- Never buy wild plants of CITES Appendix-I species. This trade is highly damaging and must be stopped.

- Avoid wild plants of other succulent species. Check with specialist nurseries who will be able to tell you the origin of their plants.

- With a few exceptions (listed below), it is highly unlikely that you will find wild succulents in garden centres or other retail outlets. If you suspect that unusual plants may be of wild origin point this out.

- The following are some of the succulents which may be wild-collected. Check carefully before you buy: Didierea, Fockea, Kedrostris, Operculicarya, Raphionacme, large plants of Nolina and Pachypodium. 


\section{CARNIVOROUS PLANTS}

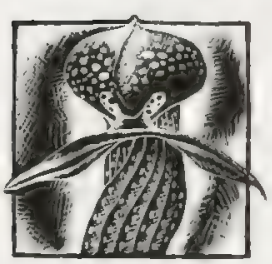

Camivorous plants, of which there are several hundred species, have been the object of fascination for centuries, arousing the interest of such renowned naturalists as Charles Darwin, who published the first major work on them in 1875 . This fascination has led many people to try their hand at growing them, and once their particular horticultural requirements are understood they can be very rewarding plants.

Unfortunately the demand for some species is so great that wild populations have been placed under threat from overcollection. This applies particularly to the Venus Flytrap Dionaea muscipula, a plant found in the wild only in the States of North and South Carolina in the USA, and described as long ago as 1763 by Arthur Dobbs, the then Governor of North Carolina, as "the great wonder of the vegetable kingdom".

The Venus Flytrap is by far the most popular and well-known of all carnivorous plants and is widely offered for sale, often as dormant "bulbs" pre-packed in containers of growing medium, but also as growing plants and, in small numbers, as plantlets in tubes for growing on. Well over a million plants in total are sold in Europe every year and a high proportion of these - probably over two thirds - are wild-collected imports from the USA with the remainder being artificially propagated, mostly in the Netherlands with some in the UK, Germany and France. The trade in Venus Flytraps is particularly wasteful as it is generally reckoned that $90 \%$ of plants die within a few weeks of being bought simply through lack of proper care.

Sufficient concern was felt that the collection of plants was damaging the wild populations, which are also under threat from the drainage of the sandy wetlands which constitute their home, that in March 1992 the species was placed in Appendix II of CITES. This allows exports of wild plants to be properly monitored; it does not ban the trade outright.

Although Venus Flytraps dominate the market for camivorous plants, several others are becoming increasing popular, notably sundews Drosera, north American pitcher plants Sarracenia, butterworts Pinguicula and bladderworts Utricularia. Other groups are regarded as more the realm of the specialist collector, although several can be bought in larger garden centres and other retail outlets. These include the tropical pitcher plants in the genus Nepenthes which require high temperatures and high humidity and are therefore in general only suitable for growing in hothouses or vivaria; the North American Cobra Lily Darlingtonia califormica which although almost hardy, is exacting in its requirements and not particularly easy to grow; the Western Australian Pitcher Plant Cephalotus follicularis, also somewhat fussy about its growing conditions; and the sun pitchers Heliamphora, primitive forms from the highlands of northern South America much sought after by collectors but rare and expensive in cultivation.

The great majority of plants offered for sale in these groups are artificially propagated, particularly the sundews, butterworts and bladderworts, for which there is no evidence of extensive trade in wild-collected plants. Plants sold in garden centres and florists are 
generally supplied by the five or six wholesale European producers, or sometimes by one of the dozen or so other specialist carnivorous plant nurseries, generally small and usually only semi-professional, found scattered throughout Europe.

However the Sarracenia species and Darlingtonia californica have in the past been wildcollected for sale to such an extent that three forms of Sarracenia are now included in CITES Appendix I, which means effectively that all international trade in wild plants is banned; the other forms of Sarracenia and Darlingtonia are all listed in Appendix II, with export of wild Darlingtonia banned under US legislation. Sarracenia is popular with collectors and many varieties and hybrids have been raised. The growing plants offered for sale in Europe are almost certainly all, or virtually all, artificially propagated but packaged rhizomes of both Sarracenia and Darlingtonia are sometimes offered by mail-order and some of these may well be wild imports.

Nepenthes plants have also attracted the interest of commercial collectors. Some species are very rare and localized and have been seriously threatened by over-collecting. The spectacular Nepenthes rajah from Mount Kinabalu in Borneo is a case in point. This species, which produces the largest pitchers of any Nepenthes — as large or larger than a football - is the most sought-after of all pitcher plants with collectors paying the equivalent of US $\$ 1000$ for healthy plants. It has now been reduced to two or three populations within Mount Kinabalu National Park which are still the subject of poaching, despite the species having been included on Appendix I of CITES since 1981. However, this damaging trade is largely to the USA and Japan, where interest in Nepenthes cultivation is concentrated, and there is no evidence of large-scale imports of wild plants into Europe.

Small quantities of wild plants of other carnivorous plant species have certainly been imported into Europe, but there is no evidence that the trade poses a serious threat to the species concerned.

- Check carefully the origin of any Venus Flytraps offered for sale. Avoid buying them if you are not satisfied that they are artificially propagated.

- Check the origin of any rhizomes of Sarracenia and Darlingtonia offered for sale by mail-order or in packages in retail outlets. Again, avoid buying them if there is any doubt that they are not artificially propagated.

- Most other carnivorous plants offered for sale are likely to have been nursery grown. 


\section{AIR PLANTS}

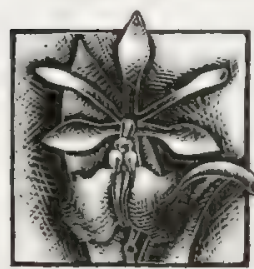

One of the most noticeable new plant fashions of recent years has been the use of "air plants" for home decoration. These attractive, miniature plants are members of the genus Tillandsia in the pineapple family, the Bromeliaceae, and are remarkable for their ability to extract all the water and nutrients they need directly from the atmosphere, using their roots solely as support. In their native haunts in Central and South America and the southern USA. they festoon trees, rocks and even telegraph poles, often in enormous numbers. The Spanish Moss which drapes itself over tree branches in the swamplands of the Deep South in the USA is also a tillandsia, $T$. usenoides.

In Europe, air plants are usually sold in high street shops and garden centres in arrangements. often of more than one species, glued onto pieces of wood, sea-shells or lumps of lava, sometimes forming elaborate miniature landscapes with model animals and humans.

These arrangements have become so popular that literally millions of plants are imported annually into Europe to meet the demand. The majority of these come from Guatemala from where in 1988 alone approximately 120 tonnes, comprising around 13 million plants, were exported to Germany and the Netherlands. Plants are also imported in smaller quantities from other Latin American countries, including Argentina, Brazil, Costa Rica, Colombia, Paraguay and Peru. There are several nurseries in Latin America which supply tillandsias for export. Considerable controversy has surrounded the extent to which plants from Central and South America are artificially propagated. The tillandsias in bulk trade are relatively easy to propagate, either by seed or by offsets from mother plants. However, the former is quite a lengthy business, as plants take up to five years to reach saleable size from seed. Offsets are quicker, taking only two or three years, but the rate of production is lower, as each mother plant produces relatively few offsets at once. Because of this, it has in the past proved cheaper to collect mature plants from the wild than to propagate them in nurseries. It is now widely accepted that until the late $1980 \mathrm{~s}$, between $50 \%$ and $70 \%$ of the plants exported from Guatemala were wild-collected. Fortunately, this situation has apparently changed considerably in the past three or four years, with the two major exporters dealing increasingly in artificially propagated plants. All these are raised from offsets, as seed propagation is only carried out by a few European and North American nurseries. The mother stock requires periodic replenishment from the wild, but this places much less strain on wild populations than direct collection for export. Nevertheless, other nurseries continue to collect from the wild, and a significant, though undoubtedly decreasing, number of wild plants still enter international trade.

The effect the trade is having on wild populations of tillandsias remains largely unknown The bulk trade concerns fewer than twenty species and is dominated by one, Tillandsia ionantha, which comprises, for example, $80 \%$ of the sales in the UK market. These species are generally widespread and abundant in their natural habitats and now artificially propagated in large numbers and there is no reason to believe that they are threatened with extinction at present. However there is evidence of local over-collection in some areas, with 
all plants stripped from accessible sites. There are reports that, as areas of Guatemala are depleted of stocks, commercial collectors are moving into neighbouring areas in Mexico, Honduras and El Salvador.

Of more concern are the large number of rare and localised species of tillandsia. These appeal to the growing band of tillandsia specialists, concentrated in Germany and the USA at present, and some are definitely under threat. They include Tillandsia sucrei from Rio de Janeiro in Brazil and Tillandsia xerographica, a spectacular slow-growing silvery species from Guatemala, Mexico and El Salvador which may take eighteen years to mature. This is one of the most sought-after of all tillandsias, and one Guatemalan nursery has reportedly exported up to 40,000 each year, the great majority, if not all of which, were until recently wild collected. Fortunately this species is now also being artificially propagated for export. Other species from the Sierra de Orgaos in southern Brazil and mountainous areas in southern Mexico and Peru are also believed threatened by collectors.

There is also concem that rare species may be inadvertently collected and exported in shipments of commoner species. Tillandsias are notoriously difficult to identify and even experts have difficulty in distinguishing many of the species.

In recognition of these problems, seven species of tillandsia thought to be particularly at risk from trade were placed on Appendix II of CITES in March 1992.

The specialist trade continues in Europe at a steady level but there is some indication that the mass demand may have already peaked, with sales in the UK falling by an estimated $50 \%$ from 1988 to 1989 . There are also encouraging signs that demand is moving towards artificially-propagated plants which are generally of higher and more uniform quality that wild-collected plants. Increasingly this improved quality is seen as offsetting the higher prices that have to be charged for nursery-raised stock. In the United Kingdom, around half the plants sold in 1989 were artificially propagated within the UK from imported parent stock and the proportion was expected to increase in the future. Previously all the plants sold had been imported. There is also large-scale artificial propagation in the Netherlands, although this as yet only amounts to a small proportion of the total trade.

These small tillandsias are not the only bromeliads which are popular as house plants. Several other, larger green-leaved tillandsias, particularly the dramatic pink-and-blue spathed T. cyanea, as well as species of Aechmea, Billbergia, Cryptanthus, Neoregelia and Vriesea are long-established in cultivation. All these are propagated in huge numbers. chiefly in the Netherlands, and wild plants are not seen in commerce.

- Buy artificially propagated air-plants in preference to wild-collected ones and definitely avoid buying wild plants of those species listed in CITES Appendix-II (Tillandsia harrissil, T. kammii, T. kautskyi, T. mauryana, T. sprengeliana, $T$. sucrei and $T$. xerographica).

- Other bromeliads offered for sale are nursery-raised. 


\section{SOURCES OF INFORMATION}

This booklet summarises the information compiled in various research reports many of which are published in the TRAFFIC Bulletin, details of which can be obtained from TRAFFIC International at the address given below. The principal investigation report is:

Jenkins, M. (1992). The wild plant trade in Europe: Results of a survey of European Nurseries, TRAFFIC Europe.

Additional references which may be useful are:

Beguin, J-J. (1992). Artificially propagated orchid source book. A.P.O Catalogues (Address - see below)

Fitzgerald, S. (1989), International Wildlife Trade: Whose business is it? WWF, Washington DC.

Fuller, D. and Fitzgerald, S. (eds) (1987). Conservation and commerce of cacti and other succulents. WWF, Washington, DC.

de Klemm, C. (1990). Will plant conservation and the law. IUCN, Cambridge.

Hunt, D. (1992). CITES Cactaceae Checklist. Royal Botanic Gardens, Kew and Intemational Organization for Succulent Plant Study (IOS).

Read, M. (1989). Grown in Holland? Flora and Flora Preservation Society.

Schouten, K. (1992). Checklist of CITES Fauna and Flora. Revised Edition 1992. CITES Secretariat, Lausanne, Switzerland.

Wijnstekers, W. (1992). The evolution of CITES. Third Revised Edition. CITES Secretariat, Lausanne, Switzerland. 


\section{USEFUL ADDRESSES}

A.P.O. Catalogues, CP 151231 Conches, Switzerland

Tel: (022) 3 470312, Fax: (022) 3477228

The Artificially propagated orchid source book can be obtained from this address.

The British Cactus and Succulent Society (BCSS)

c/o 26, Glenfield Road, Banstead, Surrey, SM7 2DG

BCSS operates a conservation and research fund which helps to fund in situ conservation projects.

CITES Secretariat, 6 rue de Maupas, Case postale 78, 1000 Lausanne 9, Switzerland Tel: (41) 21 200081, Fax: (41) 21200084

The Cyclamen Society

c/o P.J.M. Moore, Tile Barn House, Standen Street, Iden Green, Benenden,

Kent TN17 4LB

The Society seeks to promote the conservation of Cyclamen in nature and in cultivation by all acceptable means. It has issued a Code of Conduct for all Cyclamen growers.

Fauna and Flora Preservation Society (FFPS), 1 Kensington Gore, London SW7 2AR Tel: 0718238899 , Fax: 0718239690

The mission of FFPS is to safeguard the future of endangered species of animals and plants. FFPS campaigns on plant trade issues, carries out research into the trade and is running the Indigenous Propagation Project in Turkey.

Plantlife, c/o Natural History Museum, Cromwell Road, London SW7 5BD

Tel: 0719389111, Fax: 0719389112

Plantlife is a broadly based conservation group set up to save plants and to campaign for plant conservation. In doing so it is creating a strong alliance of botanists, gardeners and conservationists.

Royal Botanic Gardens, Kew, Richmond, Surrey, TW9 3AB

Tel: (44) 81940 1171, Fax: (44) 819481197

TRAFFIC International, 219c Huntingdon Road, Cambridge CB3 ODL

Tel: (44) 223 277427, Fax: (44) 223277237

TRAFFIC Europe-Regional Office, Chaussée de Waterloo 608, 1060 Brussels, Belgium Tel: (32) 23470111 , Fax: (32) 23440511

World Conservation Monitoring Centre, 219c Huntingdon Road, Cambridge CB3 ODL Tel: (44) 223277314, Fax: (44) 223277136 


\section{ANNEX 1: Plant species listed in CITES Appendices I and II}

as of 11 June 1992

Flora

Agavaceae
I

Agave arizonica

Agave paniflora

Nolina interrata

\section{Amaryllidaceae}

Apocynaceae
II

Agave victoriae-reginae \#1

Galanthus spp. \#1

Sternbergia spp. \#1

Pachypodium spp.*\#1

Pachypodium baronii

Pachypodium brevicaule

Pachypodium decaryi

Pachypodium namaquanum

Rauvolfia serpentina \#2

Alocasia sanderiana \#1

Araceae

Panar quinquefolius \#3

Araliaceae

Araucaria araucana* -113 \#1

Araucariaceae

Araucaria araucana **+217

Ceropegia spp. \#1

Frerea indica \#

Berberidaceae

Podophyllum hexandrum $=376 \# 2$

Bromeliaceae

Tillandsia harrisii \#1

Tillandsia kammii \#1

Tillandsia kautskyi \#1

Tillandsia mauryana \# 1

Tillandsia sprengeliana \#1

Tillandsia sucrei \#1

Tillandsia xerographica \#1

Byblidaceae

Byblis spp. \#1

\section{Cactaceae}

Ariocarpus spp.

Astrophytum asterias $=377$

Aztekium ritteri

Coryphantha minima $=378$

Coryphantha sneedii $=378$

Conphantha werdermannit

Discocactus spp.

Disocactus macdougallii $=379$

Echinocereus ferreirianus

var. lindsayi $=380$

Echinocereus schmollii $=381$

Leuchtenbergia principis

Mammilaria pectinifera $=382$

Mammillaria plumosa

Mammilaria solisioides

Melocactus conoideus

Melocactus deinacanihus

Melocactus glaucescens

Melocactus paucispinus

Obregonia denegrii

Pachycereus militaris $=383$

Pediocactus bradyi $=384$

Pediocactus despainit

Pediocactus knowltoni $=384$

Pediocactus papyracanthus $=385$

Pediocactus paradinei
Cactaceae spp, $* 44$ 
Pediocactus peeblesianus $=384$

Pediocactus sileri

Pediocachus winkleri

Pelecyphora spp.

Sclerocactus brevihamaticus $=386$

Sclerocactus glaucus

Sclerocactus erectocentrus $=387$

Sclerocactus mariposensis $=387$

Sclerocactus mesae-verdae

Sclerocactus pubispinus

Sclerocactus wrightiae

Strombocactus disciformis

Turbinicarpus spp. $=388$

Uebelmannia spp.

\begin{tabular}{|c|c|c|}
\hline Caryocaraceae & & Caryocar costaricense \#1 \\
\hline Cephalotaceae & & Cephalotus follicularis \#1 \\
\hline $\begin{array}{l}\text { Compositae } \\
\text { (Asteraceae) }\end{array}$ & Saussurea costus $=389$ & \\
\hline Crassulaceae & Dudleya stolonifer & Dudleya iraskiae \\
\hline Cupressaceae & $\begin{array}{l}\text { Fitzroya cupressoides } \\
\text { Pilgerodendron uviferum }\end{array}$ & \\
\hline
\end{tabular}

Cyatheaceae

Cycadaceae
Cyatheaceae spp. \#1

Cycadaceae spp. * \#1

Cycas beddomei

\begin{tabular}{|c|c|c|}
\hline Diapensiaceae & & Shortia galacifolia \#1 \\
\hline Dicksoniaceae & & Dickonsiaceae spp. \#1 \\
\hline Didiereaceae & & Didieraaceae spp. \#1 \\
\hline Dioscoreaceae & & Dioscorea deltoidea \#1 \\
\hline Droseraceae & & Dionaea muscipula \#1 \\
\hline Ericaceae & & Kalmia cuneata \#1 \\
\hline Euphorbiaceae & $\begin{array}{l}\text { Euphorbia ambovombensis } \\
\text { Euphorbia cylindrifolia } \\
\text { Euphorbia decaryi } \\
\text { Euphorbia francoisii } \\
\text { Euphorbia moratii } \\
\text { Euphorbia parvicyathophora } \\
\text { Euphorbia primulifolia } \\
\text { Euphorbia quartziticola } \\
\text { Euphorbia tulearensis }\end{array}$ & Euphorbia spp. -114 \#1 \\
\hline Fouquieriaceae & $\begin{array}{l}\text { Fouquieria fasciculata } \\
\text { Fouquieria purpusii }\end{array}$ & Fouquieria columnaris \#1 \\
\hline Juglandaceae & & Oreomunnea pterocarpa $=390 \# 1$ \\
\hline $\begin{array}{l}\text { Leguminosae } \\
\text { (Fabaceae) }\end{array}$ & Dalbergia nigra & $\begin{array}{l}\text { Pericopsis elata \#5 } \\
\text { Platymiscium pleiostachyum \#1 }\end{array}$ \\
\hline Liliaceae & $\begin{array}{l}\text { Aloe albida } \\
\text { Aloe pillansii } \\
\text { Aloe polyphylla } \\
\text { Aloe thorncroftii } \\
\text { Aloe vossii }\end{array}$ & Aloe spp. * \#6 \\
\hline
\end{tabular}


Mel:aceae

Nepenthaceae

Nepenthes khasian

Nepenthes rajah

\section{Orchidaceae}

Cattleya skimneri

Cattleya trianae

Didicica cunninghami

Laelia jongheana

Laelia lobata

Lycaste skinneri var. alba $=392$

Paphiopedilum spp.

Peristeria elata

Phragmipedium spp.

Renanthera imschooriana

Vanda coerulea

Palmae

(Arecaceae)
Swietenia humilis \#1

Swietenia mahagoni \#5

Nepenthes spp. * \#1

Orchidaceae spp. *

$=391 \# 7$
Chrysalidocarpus decipiens \# Neodypsis decaryi \#1

$\begin{array}{ll}\text { Pinaceae } & \text { Abies guatemalensis } \\ \text { Podocarpaceae } & \text { Podocarpus parlatore }\end{array}$

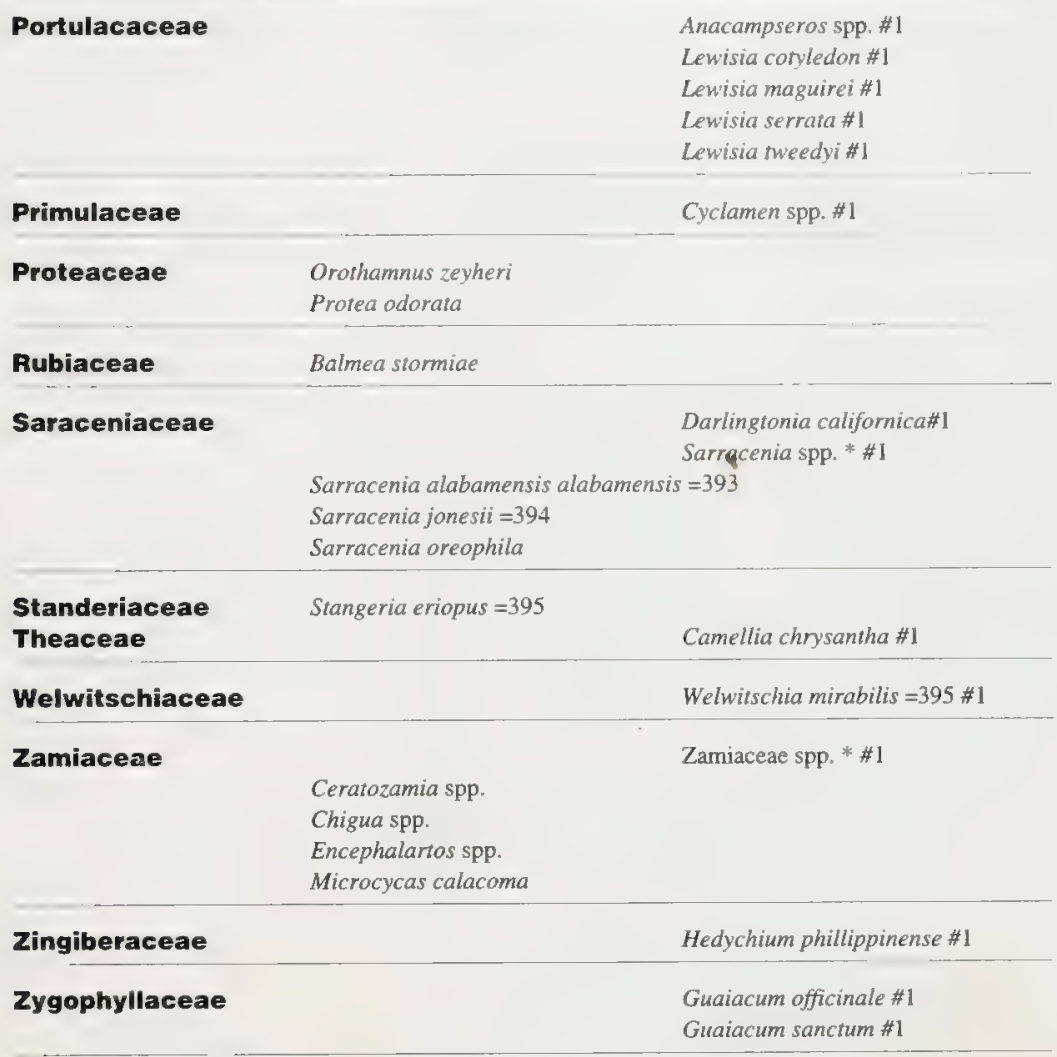




\section{NOTES}

+217 Population of Chile

-114 All species that are not succulent

$=376$ Also referenced as Podophyllum emodi

$=377$ Also referenced in genus Echinocactus

$=378$ Also referenced in genus Escobaria

$=379$ Also referenced as Lobeira macdougallii or as Nopalxochia macdougallii

$=380 \quad$ Also referenced as Echinocereus lindsayi

$=381$ Also referenced as Wilcoxia schmollii

$=382$ Also referenced as Solisia pectinata

$=383$ Also referenced as Backebergia militaris

$=384$ Also referenced in genus Toumeya

=385 Also referenced in genus Toumeya or in genus Sclerocactus

=386 Also referenced as Ancistrocactus tobuschii

$=387$ Also referenced in genus Neolloydia or in genus Echinomastus

$=388$ Also referenced in genus Neolloydia

$=389$ Also referenced as Saussurea lappo

$=390$ Also referenced as Engelhardia pterocarpa

$=391$ Includes families Apostasiaceae and Cypripediaceae as subfamilies Apostasiodeae and Cypripedioideae

$=392$ Also referenced as Lycaste virginalis var. alba

$=393$ Also referenced as Sarracenia rubra alabamensis

$=394$ Also referenced as Sarracenia nubra jonesit

$=395$ Includes synonym Stangeria paradoxa

$=396$ Includes synonym Welwitschia bainesi

In accordance with Article 1, paragraph b, sub-paragraph (iii), of the Convention, the symbol (\#) followed by a number placed against the name of a species or higher taxon included in Appendix II designates parts or derivatives which are specified in relation thereto for the purposes of the Convention as follows:

\#1 Designates all parts and derivatives, except:

a) seeds, spores and pollen (including pollinia); and

b) tissue cultures and flasked seedling cultures

\#2 Designates all parts and derivatives, except:

a) seeds and pollen;

b) tissue cultures and flasked seedling cultures; and

c) chemical derivatives

\#3 Designates roots and readily recognisable parts thereof

\#1 Designates all parts andderivatives, except:

a) seeds and pollen;

b) tissue culture and flasked seedling cultures;

c) fruits and parts and derivatives thereof of naturalized or artificially propagated plants; and

d) separate stem joints (pads) and parts and derivatives thereof of naturalized or artificially propagated plants of the genus Opuntia subgenus Opuntia

\#5 Designates saw-logs, sawn wood and veneers

\#6 Designates all parts and derivatives, except:

a) seeds and pollen:

b) tissue cultures and flasked seedling cultures; and

c) separate leaves and parts and derivatives thereof of naturalized or artificially propagated plants of the species Aloe vera

\#7 Designates all parts and derivatives, except:

a) seeds and pollen (including pollinia);

b) tissue cultures and flasked seedling cultures;

c) cut flowers of artificially propagated plants; and

d) fruits and parts and derivatives thereof of artificially propagated plants of the genus Vanilla 

Printed on recycled paper. 


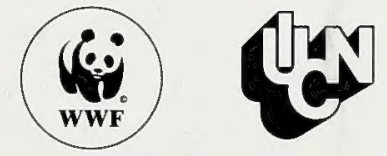

The TRAFFIC Network is the world's largest wildlife trade monitoring programme with offices covering most parts of the world. TRAFFIC is supported by WWF (World Wide Fund For Nature) and IUCN (the World Conservation Union) to monitor trade in and utilisation of wild plants and animals. It works in close co-operation with the Secretariat of the Convention on International Trade in Endangered Species of Wild Fauna and Flora (CITES). As the majority of its funding is provided by WWF, the Network is administered by the WWF Programme Committee on behalf of WWF and IUCN.

The TRAFFIC Network shares its international headquarters in the United Kingdom with the World Conservation Monitoring Centre.

For further information contact:

The Director

TRAFFIC International

219 c Huntingdon Road

Cambridge CB3 0DL

United Kingdom

Telephone: (0223) 277427

Fax: (0223) 277237

Telex: 817036 SCMU G
The Director

TRAFFIC Europe

Regional Office

Chaussée de Waterloo 608

1060 Brussels

Belgium

Telephone: (32) 23470111

Fax: (32) 23440511 